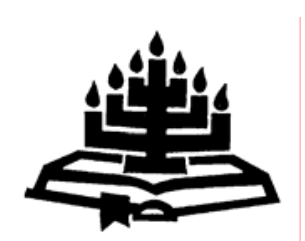

\title{
The suffering witness: a missiological reading of Lamentations
}

\author{
Bob Wielenga \\ Reformed Mission \\ RICHMOND \\ E-mail: wielenga@pmburg.co.za
}

Abstract

The suffering witness: a missiological reading of Lamentations

This article explores the possibilities of a missiological reading of the book of Lamentations. Based upon a historical understanding of Lamentations, Christological conclusions are drawn from it with a view on formulating some missiologically relevant guidelines for missionary praxis. This article contends that Lamentations was composed to be used pastorally in an unprecedented crisis in Jerusalem in 586 BCE. In a situation of utter powerlessness and otherlessness the lamenting population was shown a way to rebuild their shattered universe by, paradoxically, reaching out to their God who was not there for them anymore. The suffering witness of Lamentations 3 is used as a Christological model, which is applied to missionary praxis. In the fields of worship and liturgy, aid and assistance and prophetic analysis the church has to continue the witnessing ministry of her Lord, empowered by his Spirit.

\section{Opsomming}

Die lydende getuie: 'n missiologiese lesing van Klaagliedere

Hierdie artikel ondersoek die moontlikhede van 'n missiologiese lesing van die boek Klaagliedere. Op grond van die historiese verstaan van Klaagliedere word Christologiese konklusies getrek met die bedoeling om 'n aantal missiologies relevante riglyne met die oog op die sendingpraktyk te formuleer. Hierdie artikel maak die stelling dat Klaagliedere geskryf is om pastoraal gebruik te word in 'n ongeëwenaarde krisis in Jerusalem in 586 v.C. In 'n situasie van absolute magteloosheid en eensaamheid word die klaende volk 'n weg gewys na die herbou van hulle verbryselde universum, paradoksaal deur middel van hulle uitreiking na hulle God, wat nie langer vir hulle daar was nie. Die lydende getuie van Klaagliedere 3 word 
gebruik as 'n Christologiese model, wat toegepas word op die sendingpraktyk. Op die terreine van aanbidding en liturgie, materiële bystand en ondersteuning, en van profetiese analise sal die kerk die getuiende bediening van haar Here in die krag van die Heilige Gees moet voortsit.

\section{Introduction}

A missiological reading of an Old Testament document like Lamentations presupposes a theological understanding of the Old Testament within the canonical context of the Christian Bible. ${ }^{1}$ Even though we consider Christology to be the heart of theology, that does not lead us to a Christological reading of the Old Testament (contra Van de Beek, 2002:37-54; cf. Van Rooy, 2001:86 ff.). To find Jesus Christ back on each page of the Old Testament can only be successfully done with the help of the allegorical methodology, as developed by church fathers like Origen (Chadwick, 1984:134-157; Meijering, 1995:35-51). In Lamentations there are no intentional references to Jesus Christ; there are no messianic intentions (cf. Renkema, 1983:336 ff.). This does not exclude a typological interpretation (Levoratti, 2001; cf. Van Rooy, 2001:92, 96) of Lamentations, which takes seriously a historical reading with its emphasis on authorial intent, but which looks for analogies between Jesus Christ and the events, realities or persons in the Old Testament from a New Testament perspective. We look in Lamentations for missionary relevant analogies, which may help us to understand and fulfil our own missionary mandate in our own times. In this article mission is defined as the church witnessing to the world in words and with deeds (Bosch, 1980; 1985:76-82; 1991:457 ff.).

In Lamentations one is confronted with the suffering of Judah, shattered by the disaster of 586 BCE. In five hymns the destruction of the city and the temple is lamented. Much in these laments is recognisable in our modern world with its disasters and calamities, caused by humankind or nature. What is the witness of the church in this world of suffering without hope and future for millions of its people? What can be said, from a missiological reading of Lamentations, to these people who are utterly powerless to change

1 For the discussion of the questions around the interpretation of the Old Testament, see Levoratti (2001:37-79); McKim (1986); Smit (1998); Nürnberger (2002); Helberg (1983). 
their own context of suffering and who are, in the process, constantly threatened by the loss of their identity?

\section{A historical reading of Lamentations}

\subsection{History and literature}

In reading the book of Lamentations, one has to deal with the usual canonical questions, which are discussed in the literature. ${ }^{2}$ They are only touched on here, as far as they are relevant to our understanding of Lamentations in the context of this article. The historical background of Lamentations is not disputed among scholars. The traumatic experience of the destruction of Jerusalem in 586 BCE has given rise to the five hymns this book contains. We agree with Renkema (1983:59-77) that the authors are to be found among the lower temple personnel, which were left behind in Jerusalem. The artistic poetry with its artificial acrostical form, which characterises the hymns, points to authors with the skills to write these highly sophisticated poems. Only among the lower cult personnel as the Levites (Korach, Asaph) could these skills be found. Also a pastoral need of the population had to be met in the absence of priests and prophets: they had to cope with the disaster and its aftermath. The pastoral care for the people had to be carried out by the few of the temple personnel left behind. In informal gatherings of the devastated population these hymns could have been used to articulate that which lived among them and to voice their cry for help. These pastoral workers channeled the raw emotions, pain and even protest towards God in order for the people to be healed and to come to terms with the things that had happened to them (see also Peterson, 1980:117).

We opt for the theological unity of the hymns in spite of the apparent differences (see Renkema, 1988; Helberg, 1984:6 ff.). The hymns must have been composed shortly after 586 BCE in Jerusalem. After the exile these hymns have gained recognition as authentic expressions of the grief of the people over the destruction of the city and the temple. They found their place in the so called Megillot, which were read during official festivals. On the 9th of $A b-$ the 5th month of the Jewish calendar - Lamentations was read during a day of mourning and fasting. Maybe an early reference to this practice of 
keeping annually such days are found in Zechariah 7:5. In modern times this official lamenting also covers the fall of Jerusalem in 70 $\mathrm{CE}$ and the subsequent suffering in the Diaspora.

\subsection{Worldview and poetry}

In a time of unprecedented crisis the foundations of one's worldview are usually radically shaken. A worldview can be described as a person's comprehensive and prereflective understanding of reality. It is an integrating framework of fundamental considerations which gives context, direction and meaning to life in the light of one's ultimate commitments (cf. Wilson as quoted in Krüger, 2004:2; Wolters, 1984). The crisis may give rise to conscious reflection, which can be articulated in cosmological narratives. As Krüger formulates (2004:3): "Cosmology can be understood as a worldview articulated in the form of a narrative." We suggest that in Lamentations we come across a worldview articulated in the form of poetry. This worldview provides us with a framework for understanding the grief and suffering, the despair and hopelessness of the people. In the literature scholars reflect upon this theme when they deal with the theology of Lamentations. Before attention is paid to the poetical form of the hymns, a short outline of the worldview which dominated the people in this specific period of time is given (Renkema, 1983:268-293; Miller \& Hayes, 1986).

In pre-exilic times the Judaeans were convinced that Jerusalem was invincible. The temple stood firm on top of mount Zion, where God dwelled among them. The Davidic monarchy was still in power as guarantee that God was with them. The Judaean state was still intact as proof of God's favour. Throne, altar and state formed the three pillars under the so-called Zion-theology, which detoriated in a full-blooded civil religion. Theologically, one could say that the covenant had become an unilateral, unbreakable contract; Israel's election had become the basis for Divine favouritism at the cost of the nations. The "Day of the Lord" message of late pre-exilic prophets as Nahum and Habakuk, full of warnings about the coming wrath of God, did not come across, directed as it was against Judah. One expected that Day to happen upon the nations (gojiem), but not upon the elected favourites of the Lord. In Lamentations 2:14 and 4:13 (false) prophets are held responsible for the people's complete misunderstanding of these prophetic warnings. ${ }^{3}$ In spite of the hard

3 For the complicated matter of false prophecy in the Old Testament, see Westermann (1970); Renkema (1983:155-171). These prophets went wrong in 
hitting prophecies of Jeremiah these fundamentals of Judaean "orthodoxy" could not be shaken, not even after 597 BCE when the first deportation to Babylon took place.

In conclusion, the basics of the Judaean worldview were gone. The centre of their symbolic universe had disintegrated. They were overcome with fear and anxiety without any prospect of a liveable future. These laments were composed to help them to reflect on what had gone wrong and how to set it right again. These reflections were facilitated by the poetical form in which they were cast.

\subsection{Lamenting and its function}

Much has recently been written on lamenting and its function. Brueggemann (2001a:15 ff.) noticed, for instance, the difference between Jewish and Christian approaches to lamenting. Jewish spirituality knows vigorous protest against God, while the Christian one is known for its submissive humility. Brueggemann pleads for a dialogical interaction between God and his people, in which there is room for speaking out against what is perceived as wrong on earth and in heaven. To break the silence, lamenting can change the situation. This "subversive activity of finding voice" (Brueggemann, 2001b:23) is not found in Lamentations. But Brueggemann opens our eyes to what happened in these laments. God is called upon to see the suffering of his people and to reconsider the outcome of his punishing actions (Lam. 1:9, 11, 20;2:20; 5:1). This crying out in laments is aimed at changing God's heart. This does not match with a submissive religious mindset. Protest is voiced against the fate of the little children: should they be eaten by the very mothers who gave birth to them (Lam. 2:20)? Protest is heard against the excessive suffering at the hands of their arch enemies, the Edomites (Lam. 4:21 ff.). This suffering is out of proportion to the punishment God decided to mete out to them through their hands. That could not have been God's intention. But the context of the lamenting in Jerusalem in 586 BCE does not allow for the bold Jewish spirituality of vigorous protest against God, which Brueggemann contends, is characteristic for lament hymns in general.

Lamenting is the language of suffering, Wolterstorff observes (2001:42 ff.). The suffering is voiced and named. Next, the suffering must be owned; it is accepted as part of one's life narrative. Then, it

sticking, selectively, to traditional truths without taking into consideration the changing of contexts. 
is voiced in a cry out to God: why? (Wolterstorff, 2001:44). There are, however, expressions of perseverance of faith in laments. Based upon retrospective remembering of God's acts in the history of his people, there is the prospect of a new intervention of God on his people's behalf. Wolterstorff's analysis is helpful in interpreting the lamenting in Lamentations. The wall of silence is broken down in these hymns; the lament is voiced, firstly by the authors of these hymns, but subsequently also by their suffering audiences, who internalised these hymns. They faced up to the terrible reality they lived in; there was no denial of what caused the collapse of their universe; lastly, they cried out to God with the prayer to restore them to Himself (Lam. 5:20).

About the function of the acrostical form of these poems a communis opinion has grown (Berges, 2001:1200; Renkema, 1993:33-36). The idea was to encourage completeness in the expression of grief, the confession of sin and the instilling of hope (Gottwald, 1962:28). The totality of the grief in all its reiterated details is loudly voiced in hymns, which remind us of hymns of mourning the dead with its qina-metrum and concentric structure.4 Helberg (1984:4) mentions the possibility that this form stresses that there is order in the midst of chaos.

\subsection{The shattering of their universe 5}

In Jerusalem the people were assisted by their pastors to come to terms with the disaster which had taken place. In interpreting Lamentations we make use of the three categories Wolterstorff applied to describe the process of coping with suffering. In Jerusalem the people learned through these hymns to face the loss of power and glory of their past and the loss of the individual and collective identity they had known before the disaster had struck. These two losses are named, owned and cried out to God. But we are left with the nagging question whether or not this whole process led to a real understanding of what had caused the disaster of 586 BCE in the first place.

4 Lamentations 5 contains a prayer with as many lines as the Hebrew alphabet has letters (22), but without the acrostical form. This form does not fit the openending of this prayer.

$5 \quad$ Van de Beek (1996:59-62) uses the term "symbolic universe" as an alternative for worldview. The terms have their origin in different scientific fields of knowledge, but point, basically, to the same concept. See also Van de Beek (2005:62 ff.). 


\subsubsection{Loss of power}

In imaginative metaphors the loss of power is named. The city, once so full of people, once great among the nations, has become like a lonely widow without anyone to comfort her in her distress (Lam. $1: 1-2)$. She is shunned by her previous lovers as a woman unclean as in her menstruation (Lam. 1:8-9). The nations Judah struck alliances with in their common struggle against Babylon, had abandoned her now (Lam. 2:16). The streets are made unsafe for women and girls by the occupation troops, plundering and raping in celebration of their victory (Lam. 1:10, 14, 20; 5:11). The strong fortifications of the city have been broken down (Lam. 2:8-9). The city, once considered to be invincible, is defenseless. The splendour of the city, with the temple on mount Zion as glorious focus point, has been buried in the rubble of ruined buildings and palaces (Lam. $2: 5 ; 4: 1)$. The famous House of David, feared among the nations when it reigned supreme, was brought down (Lam. 2:9; 4:7, 20). They have become slaves in their own city, forced to serve the new masters, begging for food and water (Lam. 5:2, 4, 8, 9). They were utterly powerless; their life was no longer in their own hands. This affected their sense of identity.

\subsubsection{Loss of identity}

What characterised Israel as a nation, was her being chosen by God. That was central to her self-understanding. She lived in the land given to her by God as her inheritance (Lam. 5:2), with Jerusalem as the invincible capital city, where the Lord Himself dwelled on mount Zion. Her identity as a nation was tied up with this foundational commitment of God to Israel. Every Israelite had a deep sense of belonging to the chosen people living in the Promised Land. But now God was absent from his dwelling place. The temple was destroyed (Lam. 2:6). There was no place anymore to meet with God. The ministry of reconciliation could not take place without the altar (Lam. 2:7), or priests - they were dead or deported or shunned (Lam. 2:6, 20; 4:13-16). No prophets were alive anymore in Jerusalem (Lam. 2:9, 20). The channels of communication with God were blocked. To cry out to God was in actual fact meaningless: He was not there for them anymore (Lam. 3:44). They experienced God as a foe, who, without pity, hunted them down as his enemies (Lam. $2: 2,4,17)$. They had no people left to comfort them (Lam. 1:2, 9, 17); but what hurt most, was that God, in his great anger, did not want to comfort them in their despair (Lam. 2:1; 3:18). They were utterly Otherless, the real cause of the loss of their identity. 


\subsection{Facing the truth?}

Paradoxically, in prayer they sought the presence of God who was absent; in lament they reached out to God who was beyond reach. Nevertheless, in their desperation, they brought their grief and distress to God, asking Him time and again to see and reconsider what happened to them (Lam. 1:9, 11, 20 ff.; 2:18, 20). They knew that it was God Himself, who in his justified anger (Lam. 1:18), punished them for their sins. They were deeply distressed about the pitiless wrath of God against them. They were aware that they themselves were to blame for God's anger. There was, certainly, awareness of $\sin$ (Lam. 1:5, 14, 18; 3:39-40; 5:16). It has correctly been pointed out that the sins are not specified and itemised, as prophets like Jeremiah did (Renkema, 1983:267 ff.). No reference is made to idolatry and the many social evils committed during the monarchial period, exposed by the prophets. One was convinced that a disaster of this magnitude must reflect the deep seated anger of God with his people. Once the term rebellion is mentioned (Lam. $1: 18$ ), but no mention is made against which commandments they had rebelled. There is certain vagueness around their awareness of sin. In Lamentations 3:40 ff. this awareness is climaxing with the call to probe their ways and to test them. It could be, as Renkema (1993:341) argues, that this vagueness is deliberate. The authors aimed at later use of their hymns in different contexts of suffering as well. The identification of the actual sins in the years previous to the 586 BCE disasters could hinder the use of the hymns by later generations. The acknowledgement of being sinful would, then, serve this goal better than the naming and owning of the concrete sins perpetrated. True as this may be, the impression remains that the facing up to the truth did not go all the way. ${ }^{6}$

\subsection{The rebuilding of their universe}

In hymn 3 the authors introduce a literary creation as a model of how to cope with the disaster and its aftermath. 7 A mentally and physically tough character, brought to his knees like his fellow citizens under the punishing hand of God (vs. 1-13), breaks his silence and voices not only his lament but also his faith. Just

6 In contrast to prophecy poetry may speak in more general terms about sin, where prophecy has to be more specific.

7 See Saebo (1998:131-143) for a discussion on the historical identity of this character. 
because of his perseverance in faith his suffering was aggravated by his fellow citizens, who mocked him for his continuing trust in God (vs. 14). His continuing trust in God was deeply problematised by his experiences of God's deafness to the cries of his people (vs. 18). All he had hoped from the Lord, expressed in the promises of old to the patriarchs (Gen. 12:3), was gone. But in spite of everything that had happened to him and his fellow citizens he showed an amazing strength of faith, grown out of the simple conclusion that they were still alive (vs. 22). Against all expectations (Amos 5:18-20), God had not completely destroyed them. 8 They had narrowly escaped death and led a bare existence in a destroyed Jerusalem, but he interprets these traumatic events in prophetic light as a show of God's compassion for his abandoned people (vs. 22). Powerless and otherless he may be, but he refuses to accept that he is Otherless indeed. He confesses in the midst of his suffering that the Lord is still good (vs. $25 \mathrm{ff}$.). He remembers from God's history with his people that $\mathrm{He}$ does not willingly bring affliction or grief to the children of men (vs. 33). Unfailing love, expressed in compassion, is what characterises the God of Israel, even though He brings grief upon people. But against his will, in 586 BCE his hand was forced by their sins. ${ }^{9}$

Holding on to faith, hope against hope, is what the authors offer their audience as a way forward into the future. There may yet be hope (vs. 29), but only in the way of a persistent crying out to God, in which one humbles oneself before Him in confession of sin (vs. 40, $50)$. In the dialogue between this lonely confessor and his fellow citizens (vs. 34-66; Renkema, 1998), a strong testimony is voiced. No prayer can get through to God (vs. 44), but his eyes will flow unceasingly, without relief, until the Lord looks down from heaven and sees (vs. 50). No one else but God is there to cry out to for help. In his suffering he witnesses to God's never ending compassion against all evidence. The loss of power does not bother him, but the loss of the Other - he refuses to accept. For him the rebuilding of his universe has already started.

8 See Jeremiah $5: 18 ; 30: 10-11 ; 46: 28$, where the promise is given that God will not completely destroy Israel.

9 See König (2002) for the problems around God and suffering. 


\subsection{In summary}

The results of the historical reading of Lamentations can be summerised as follows:

- The original function of the laments was a pastoral one. They were composed and used to help people cope with their situation of suffering. Their subsequent use in the liturgical setting of days of mourning in post-exilic Judaism prevented that the suffering was being forgotten. Liturgical lamenting served the memory of the people with a view on future pastoral use of the experienced suffering in the past.

- The hymns helped the people to articulate their suffering against the background of their shattered symbolic universe with a view on rebuilding it. Central in the process of rebuilding was the reorientation on God, based upon what they knew of Him from their common history, as is articulated in the 3rd Hymn. This reorientation restored their lost identity (Lam. 5:21).

- In spite of the growing awareness of their sinfulness and their deepening submission to a God who was justifiably angry with them, the omission of any analysis of the sins, which caused God to bring down upon them his judgment, seems to indicate a lack of real knowledge of their sins. A radical turning around away from their sins to God in absolute repentance, did not take place, as the history of the Second Temple era reveals (see Neh. 5; 13). God's judgment was accepted but not fully understood.

\section{The suffering witness}

Which missionary fruits do this historical reading of Lamentations produce, which are missiologically relevant? As referred to in the introduction, we will look for analogies between the message of Lamentations and Jesus Christ with a view on drawing conclusions which are relevant for missions in our own times.

\subsection{Christological analogies}

It is not advisable to see an analogy between the suffering Christ and the suffering people of Judah and Jerusalem. ${ }^{10}$ But a

10 Burden (1987:70), Renkema (1983:325 ff.) and others pay attention to the relationship between Lamentations and Deutero-Isaiah. The questions, unanswered in Lamentations, are dealt with by the anonymous prophet of the exile. The suffering witness in Lamentations 3 finds his counterpart in the 
comparison with one of them could prove to be fruitful: the suffering witness of Lamentations 3 occupied his own space among them. There are some striking analogies between him and Jesus Christ to be noted, while we acknowledge the profound difference between them because of Jesus' being the unique Son of God.11

The witness of Lamentations 3 shared in the suffering of his fellow citizens, while he, at the same time, is at odds with them in his expectation of the future. He struggled with the same questions, but he differed with them in his searching for the answers. We notice his persistent witness to God's compassion and unfailing love in spite of his suffering. Against all evidence and his own present experiences he is convinced that God only unwillingly brings judgement on people - essentially, $\mathrm{He}$ is a God of love. This was also the message of Jesus Christ, who shared in the suffering of humankind through his incarnation (Phil. 2:7), but who witnessed to the same compassion and unfailing love of God. Just in his suffering at the cross $\mathrm{He}$ was pre-eminently the witness to God's reluctance to bring judgement to the world. The judgement was upon him (Is. 53). Clearly, one of the differences between these two suffering witnesses is also that Jesus has always had the ear of God. While the witness of Lamentations could go no further than there may yet be hope (Lam. 3:29), Jesus on the cross was the incarnated hope Himself. God will never be beyond reach anymore for anyone who reaches out to Him in Jesus' name (Hebr. 4:14 ff.).

We noticed how the witness of Lamentations 3 did not loose his identity, in spite of his powerlessness and otherlessness, because of his orientation on God. This is what strikes us also in Jesus' life. Utterly powerless and otherless at the cross, Jesus did not loose his identity. Even in his death He remained who He was: the incarnated God carrying divine judgement over sin (Van de Beek, 1998:149 ff., 158). Powerlessness was rather gain than loss (Phil. 3:7 ff.). He was completely dependent on God, and it was exactly this dependency that determined his identity. He was not disappointed in this trust; He was raised from the dead on the third day with consequences on a personal and cosmic scale (1 Cor. 15:12 ff.). Without others He

suffering servant of Isaiah 53 , even though we have to keep the uniqueness of the suffering servant in view. See Bosch (1980:74 ff.) for the relationship between witnessing and suffering in Isaiah 53.

11 For the modern discussions around Christology, see McGrath (1998:319-385), Demarest (1997), Van de Beek (1998), Kamphuis (1999) and Kuitert (1999). 
may have been at the end, but He never was Otherless, specifically not at the end (John 19:30; Luke 23:46).

Another consideration has to be added, however. Faced with Jesus Christ, one is confronted with the brokenness and sin of humankind (John 3:17 ff.), the frustration and meaninglessness of a groaning creation (Rom. 8:18 ff.). The crucifixion of Jesus Christ forces upon us precisely the need to thoroughly analyse the roots and causes of suffering, when disasters and calamities come upon us (Col. 2:14). We can not avoid the questions of human guilt and divine judgement, whatever the result of our discussions may be. It was precisely such an analysis that was not available in the hymns of the pastors in Jerusalem in 586 BCE. In his encounter with sinners, Jesus named the sin and expected a break with it, as his encounter with Zacheus shows (Luke 19:1 ff.). Also He refused to name human sin as cause of a calamity (Luke 13:4). In this line Paul wrote about the meaninglessness of creation is victim of (Rom. 8:20). By definition, meaninglessness can not be explained and eludes rational analysis. Thus, what happens to creation is not referred back to God as the omnipotent cause; it is seen as part of an abnormal world, which falls short of its intended goal (paradise lost). Jesus dealt pastorally with people in their sin and suffering. His has not a soft but a firm approach towards roots and causes of guilt and the need to have a view on ushering in a new and changed situation. Even the theologically difficult question of God's final judgement is not avoided in his discussions and dialogues - it was part of his apocalyptic worldview. 12

\subsection{Ecclesiological implications}

For the purpose of this article, the church is defined as the people of God, called to continue Jesus' ministry of witnessing to the world (see Berkouwer, 1972:226-262; Heyns, 1977 and Hoek, 1996:403 ff.). For that specific reason the church is empowered by the Holy Spirit to go out into the world as his suffering witness. Her witness takes the form of intercession, proclamation, aid and assistance, and prophetic witness (Berkhof, 1993:407 ff.). Alas, there is no witnessing without suffering. There is suffering because of her witness in a hostile world (marturia); there is suffering which belongs to being a human in a broken world, in a creation which is victim of

12 For Jesus and the apocalyptic, see Wright (1992:387 ff.), Witherington (1999:216 ff., 246 ff.) and Wielenga (2002:111-119). 
meaninglessness (e.g. the 2004 Tsunami in South-East Asia); there is man-made suffering on a personal and a supra-personal level (e.g. poverty, famine, war). The church can not continue Jesus' ministry of witnessing, if she tries to steer clear of suffering in whatever form she may meet it (Bosch, 1979:74 ff.). ${ }^{13}$

Based upon our historical reading of Lamentations, some missionary conclusions are now drawn from our Christological reflections. We adapt Berkhof's four forms of ecclesiastical witnessing and use the following categories as guidelines for our discussion: liturgy and worship, aid and assistance and prophetic analysis. We restrict ourselves to a discussion of the church's witness to the world in the context of suffering.

\subsubsection{Liturgy and worship}

The importance of liturgy and worship for the social action of the church in the world has already been pointed out by Wolterstorff as long ago as 1981 (1983:147 ff.; cf. De Klerk, 1999:326 ff.). 14 In this section we contend that liturgy and worship have the same importance for mission (Du Preez, 1992; also Dietterich, 1996:363 ff.; De Klerk, 2000:465 ff.). Mission flows from the church in worship, structured by her liturgy (Hoek, 1996:420 ff.). The heart of worship is the thankful remembrance of what God has done in his compassion for the world through the crucified Christ, who is risen, expectant of his return and the arrival of his kingdom. In the context of the liturgy the worshipping church brings through intercession to God's attention the suffering of the world, 15 especially the suffering of those who have lost their voice in suffering and have been silenced by their grief or have been forced into silence by oppression. The persistent intercession of the church in worship is based upon God's compassion in Jesus Christ and aimed at his intervention on behalf of those who suffer. This should be preceded by a liturgy of

13 This does not mean that the church should cultivate suffering, as if it is in itself spiritually and theologically; something positive or even salvific - see Campenhausen (1974:79 ff.).

14 This was discussed in his Kuyper-lectures at the Free University of Amsterdam. The relationship between liturgy and mission has been highlighted by Du Preez (1992). Bosch (1980; 1991) did not pay special attention to this relationship. In the two volumes, dedicated to his missiology (Saayman, 1990; 1996), this issue is not raised at all.

15 For a modern discussion of the perennial question of theodicee, see for instance Houtepen (1997). 
lamenting, in which the suffering is named and owned and lamented, helping the victims of suffering to come to terms with what happened to them, but also confronting perpetrators of suffering with their responsibilities for what happened. The church goes into this suffering, identifying herself with it. Even a church without any means to reach out to a suffering world because of utter powerlessness, is nevertheless entrusted with the powerful weapon of prayer and intercession (see Berkhof, 1993:479, 485), following her Lord in his ministry of prayer.

\subsubsection{Aid and assistance}

In the concrete contexts of suffering on a personal or supra-personal level the church has to reach out in creative ways to the people to assist them with the message of God's goodness and unfailing love in Jesus Christ. This should certainly be done by giving emergency aid or financial support (Berkhof, 1993:362 ff.). However, not less important is reaching out to people in suffering through demonstrating God's love for them by being present and listening with compassion. The assistance can also be given in the form of helping to voice the suffering by breaking the silence and thematising the hard questions, which follow in its wake. Especially this theological ministry is vulnerable to misunderstanding and could be challenged and disputed by her audiences, as happened to the suffering witness in Lamentations 3 and the suffering servant of Isaiah 53. When the hard questions are raised about human responsibility for suffering, about the possibility of divine judgement in suffering, the chance of outright rejection will be great, be it from different audiences. But a compassionate reaching out to a suffering world can not abandon this most basic of tasks of a witnessing church.

\subsubsection{Prophetic analysis}

It is the prophetic calling of the church16 to analyse the roots and causes of suffering in any form she may encounter it. Especially

16 In this context, church means not just the local church or congregation, which very often lacks the skills and means for prophetic analysis; she is mostly not in a position to publicly address problems, which are politically explosive. The suffering for prophetic witnessing is very real on grass root level. Church is here referring to the church in her federal meetings or ecumenical councils. There should be cooperation between the ecclesia in loco and the ecclesia oecumenica, an osmosis between the catholicity and the contextuality of the church with regard to this ministry of the church (Bosch, 1974:32). 
when it concerns suffering in the public domain, the church has a calling to witness about it to the relevant authorities. This analysis is theological by nature; socio-economic and political analyses are mostly better done by specialised NGOs and civil institutions, equipped for this task. But the church has an own responsibility towards her Lord to focus in her analysis on the demands of his Word. The church has to call (structural) sins by their names and perpetrators, be it persons, institutions or governments, to accountability. This prophetic witness should give hope to the victims of suffering, pointing a way forward to a sustainable future. Sometimes suffering is not fruit of sin, but is part of the meaninglessness our broken world is still victim of. Also that has to be said on the basis of a prophetic analysis of the situation. Prophetic analysis belongs to the theological ministry of the church.

\section{In conclusion}

Loss of power does not need to bother the church witnessing to the world. Loss of numbers and influence could not be counted as loss but as gain. Her identity is not at stake as long as she follows as her Lord the suffering servant, who witnessed to the world and her suffering pre-eminently from the cross. Continuing Jesus' witnessing ministry safeguards her identity the best. As the suffering witness of Lamentation 3 shows, refined by suffering the church herself is spiritually better equipped to witness to the world in her manifold suffering than as a church full of glory and conscious to the need of protecting her position in the world. Without cultivating suffering, the church should be a suffering witness like her Lord.

Worship, liturgically structured, is the heart of the life of the church. It is just there that she is empowered and equipped for her witnessing ministry. In worship the church meets her Lord and is sent out into the world with his message of hope beyond suffering. The crucified One is also the risen One, Who has promised to return. Against this background of hope the ongoing witness in suffering is sustainable and will bear fruit.

\section{List of references}

ALBREKTSON, B. 1963. Studies in the text and theology of the book of Lamentations. Lund: Gleerup.

BERGES, U. 2001. Klaagliederen. (In Eynickel, E., Noort, E., Baarda, T. \& Denaux, A., reds. Internationaal commentaar op de Bijbel. Vol. 2. Kampen: Kok/Averbode. p. 1199-1206.) 
BERKHOF, H. 1993. Christelijk geloof: een inleiding tot de geloofsleer. 7de dr. Callenbach: Nijkerk.

BERKOUWER, G.C. 1972. De Kerk. II. Kampen: Kok. (Dogmatische studiën.)

BOSCH, D.J. 1974. Het evangelie in Arikaans gewaad. Kampen: Kok.

BOSCH, D.J. 1979. Heil van die wêreld: die Christelike sending in teologiese perspektief. Pretoria: NG Kerkboekhandel.

BOSCH, D.J. 1980. Witness to the world: the Christian mission in theological perspective. Atlanta: John Knox.

BOSCH, D.J. 1985. In search of a new evangelical understanding. (In Nicholls, B., ed. In word and deed: evangelism and social responsibility. Lausanne: LCWE / WEF. p. 63-84.)

$\mathrm{BOSCH}$, D.J. 1991. Transforming mission: paradigm shifts in theology of mission. Mary Knoll: Orbis.

BRUEGGEMANN, W. 2001a. The Friday voice of faith. Calvin theological journal, 36(1):12-21.

BRUEGGEMANN, W. 2001b. Voice as counter to violence. Calvin theological journal, 36(1):22-33.

BURDEN, J.J. 1987. Klaagliedere. (In Burden, J.J. \& Prinsloo, W.S., reds. Tweegesprek met God. Kaapstad: Tafelberg. p.150-174.)

CAMPENHAUSEN, H. VON. 1974. Das Martyrium in der Mission. (In Frohnes, H. \& Knorr, U.W., Reds. Kirchengeschichte als Missionsgeschichte. Band 1. München: Kaiser. p. 71-85.)

CHADWICK, H. 1984. Origenes. (In Greschat, M., Red. Gestalten der Kirchengeschichte: alte Kirche. Band I. Stuttgart: Kohlhammer. p.134157.)

DE KLERK, B.J. 1999. Vaartversnelling vra verdieping van ons liturgie. In die Skriflig, 33(3):311-310.

DE KLERK, B.J. 2000. Liturgiese identiteitsvorming as antwoord op die invloed van die gebruikerskultuur. In die Skriflig, 34(4):451-469.

DEMAREST, B. 1997. The cross and salvation: the doctrine of salvation. Wheaton: Crossway Books. (Foundations of evangelical theology.)

DIETTERICH, I.T. 1996. A particular people: towards a faithful and effective ecclesiology. (In Hunsberger, G.R. \& Van Gelder, C., eds. Church between gospel and culture: the emerging mission in North America. Grand Rapids: Eerdmans. p. 347-369.)

DU PREEZ, J. 1992. Sendingperspektiewe in die erediens. Kaapstad: NG Kerkuitgewers. (Stellenbosse teologiese studies, nr. 18-19.)

GOTTWALD, N.K. 1962. Studies in the book of Lamentations. London: SCM.

HELBERG, J.L. 1983. Verklaring en prediking van die Ou Testament. Potchefstroom: Potchefstroomse Teologiese Publikasies.

HELBERG, J.L. 1984. Klaagliedere: ontnugtering en hoop. Pretoria: Heer Drukkers.

HEYNS, J.A. 1977. The Church. Pretoria: NG Kerk Boekhandel.

HOEK, J. 1996. Geheim en gestalte van de gemeente: over de kerk. (In Van den Brink, G. et al. Gegrond geloof: kernpunten van de geloofsleer in Bijbels, historisch en belijdend perspectief. Zoetermeer: Boekencentrum. p. 401-434.)

HOUTEPEN, A.H.J. 1997. God: een open vraag. 2e druk. Zoetermeer: Meinema. 
KAMPHUIS, B. 1999. Boven en beneden: het uitgangspunt van de Christologie en de problematiek van de openbaring nagegaan aan de hand van de ontwikkelingen bij Karl Barth, Dietrich Bonhoeffer en Wolfhart Pannenberg. Kampen: Kok. (Th.D.-thesis: Theologische Universiteit van Apeldoorn, Nederland.)

KÖNIG, A. 2002. God, waarom lyk die wêreld só? Wellington: Lux Verbi.BM.

KRÜGER, J.J.F. 2004. Switching universes: moving from a cosmology of fear and animosity to one of reconciliation in Colossians. (Unpublished paper delivered at the International Meeting of the Society of Biblical Literature \& The European Association of Biblical Literature. Groningen, Nederland. 26.07.2004.)

KUITERT, H.M. \& VAN DE BEEK, A. 1999. Jezus: bij hoog en bij laag: de Christologie van H.M. Kuitert en A. van de Beek. Kampen: Kok.

LEVORATTI, A.J. 2001. De interpretatie van de Bijbel. (In Eynickel, E., Noort, E., Baarda, T. \& Denaux, A., reds. Internationaal commentaar op de Bijbel. Band 1. Kampen: Kok/Averbode. p. 37-69.)

McGRATH, A.E. 1998. Christian theology: an introduction. 2nd ed. Oxford: Blackwell.

McKIM, D.K., ed 1986. A guide to contemporary hermeneutics: major trends in Biblical interpretation. Grand Rapids: Eerdmans.

MEIJERING, E.P. 1995. Klassieke gestalten van Christelijk geloven en denken: van Irenaeus tot Barth. Amsterdam: Gieben.

MILLER, J.M. \& HAYES, J.H. 1986. A history of ancient Israel and Judah. London: SCM.

NÜRNBERGER, K. 2002. Theology of the Biblical witness: an evolutionary approach. Münster: Lit Verlag.

PETERSON, E.H. 1980. Five smooth stones for pastoral work. Grand Rapids: Eerdmans.

RENKEMA, J. 1983. "Misschien is er hoop ...": de theologische vooronderstellingen van het boek Klaagliederen. Franeker: Wever. (Th.D.thesis: Theologische Universiteit Kampen.)

RENKEMA, J. 1988. The literary structure of Lamentations (I-IV). (In Van der Meer, W. \& De Moor, J.C., eds. The structural analysis of Biblical and Canaanite poetry. Sheffield: Sheffield Academic Press. p. 294-396.) (JSOT SS, 74.)

RENKEMA, J. 1993. Klaagliederen. Kampen: Kok.

RENKEMA, J. 1998. Lamentations: a historical commentary on the Old Testament. Leuven: Peeters.

SAAYMAN, W.A. \& KRITZINGER, J.N.J., eds. 1990. Mission in creative tension: a dialogue with David Bosch. Missionalia, 18(1): April.

SAAYMAN, W.A. \& KRITZINGER, J.N.J., eds. 1996. Mission in bold humility: David Bosch's work considered. Mary Knoll: Orbis.

SAEBO, M. 1998. Who is "the man" in Lamentations 3.1? (In Saebo, M. On the way to canon: creative tradition history in the Old Testament. Sheffield: Sheffield Academic Press. p. 131-143.) (JSOT SS, 191.)

SMIT, D.J. 1998. Biblical hermeneutics: the 20th century. (In Maimela, S.S. \& König, A., eds. Initiation into theology: the rich variety of theology and hermeneutics. Pretoria: Van Schaik. p. 297-318.)

VAN DE BEEK, A. 1996. Schepping: de wereld als voorspel voor de eeuwigheid. Nijkerk: Callenbach. 
VAN DE BEEK, A. 1998. Jezus Kurios: de Christologie als hart van de theologie. Kampen: Kok. (Spreken over God, I,1.)

VAN DE BEEK, A. 2002. De kring om de Messias: Israel als volk van de lijdende Heer. Zoetermeer: Meinema. (Spreken over God, I,2.)

VAN DE BEEK, A. 2005. Toeval of schepping? Scheppingstheologie in de context van het moderne denken. Kampen: Kok.

VAN ROOY, H.F. 2001. Christusprediking uit die Ou Testament: 'n nuwe benadering tot 'n ou probleem. In die Skriflig, 35(1):81-100.

WESTERMANN, C. 1970. Kultprophetie und Gerichtsverkündigung in der späten Königszeit Israels. Neukirchen-Vluym: Neukirchener Verlag.

WESTERMANN, C. 1990. Die Klagelieder: Forschungsgeschichte und Auslegung. Neukirchen-Vluyn: Neukirchener Verlag.

WIELENGA, B. 2002. Mission and the apocalyptic: a perspective from Matthew. International review of mission, 91(360):111-119.

WITHERINGTON III, B. 1999. Jesus the Seer: the progress of prophecy. Peabody: Hendrickson.

WOLTERS, A.M. 1984. Creation regained: Biblical basics for a reformational worldview. Grand Rapids: Eerdmans.

WOLTERSTORFF, N. 1983. Until justice and peace embrace. Kampen: Kok.

WOLTERSTORFF, N. 2001. If God is good and sovereign, why lament? Calvin theological journal, 36(1):42-52.

WRIGHT, N.T. 1992. The New Testament and the people of God. Minneapolis: Fortress. (Christian origins and the question of God, vol. I.)

\section{Key concepts:}

Christology and ecclesiology lamentations and mission

witness in suffering

worship and suffering

Kernbegrippe:

Christologie en ekklesiologie erediens en lyding getuienis in lyding klaagliedere en sending 